\title{
BIOMASS TURNOVER IN Brachiaria CULTIVARS IN A TROPICAL ENVIRONMENT
}

\section{FLUXO DE BIOMASSA EM CULTIVARES DE Brachiaria EM AMBIENTE TROPICAL}

\author{
Cláudia de Paula REZENDE ${ }^{1}$; Thasia M MACEDO ${ }^{2}$; José M PEREIRA ${ }^{1}$; \\ Ricardo M BELLOMI ${ }^{3}$; Gleidson Giordano Pinto de CARVALHO ${ }^{4 *}$; \\ Manuela Silva Libânio TOSTO ${ }^{4}$; Luís GA CIRNE; ${ }^{5}$ \\ Camila Maida de Albuquerque MARANHÃ ${ }^{6}$
}

1. Executive Committee of the Plan of Cocoa Farming, Itabela, BA, Brazil; 2. Federal University of Minas Gerais, Belo Horizonte, MG, Brazil; 3. Animal Scientist; 4. Federal University of Bahia, Salvador, BA, Brazil. manetosto@ hotmail.com; 5. Federal University of Roraima, Boa Vista, RO, Brazil; 6. State University of Montes Claros, Janaúba, MG, Brazil.

\begin{abstract}
The experiment was conducted to evaluate the morphogenetic traits of three Brachiaria cultivars (common, Llanero and Tupi) subjected to continuous grazing with variable stocking rate in the four seasons of the year. A randomized block design with five replicates was adopted. Tissue turnover evaluations were carried out in the summer, fall, winter and spring, with measurements taken every two days. Stem length and the length of each green leaf were measured. With these determinations, the following variables were calculated: stem elongation rate $(\mathrm{cm} /$ tiller/day), leaf elongation rate ( $\mathrm{cm} /$ leaf/day), number of live leaves per tiller and phyllochron (days/leaf). The highest leaf appearance rate was obtained by Tupi grass in the summer, and the lowest by Llanero grass in the winter. The lowest phyllochron, 5.90 days/leaf, was obtained by Tupi grass in the winter, whereas in commercial cultivars Llanero and common the average phyllochron was 9.04 and 10.04 days/leaf, respectively. Because of the effect of the transition from the dry season to the beginning of rains in the summer, this was the period of greatest variations in results among the different cultivars. Llanero grass stood out for the highest values for plant, tiller and leaf lengths, resulting from greater stem and leaf elongation rates. Tupi grass had the worst performance of all cultivars.
\end{abstract}

KEY WORDS: Leaf enation. Phyllocladaceae. Phyllochron. Structure (Source: CAB thesaurus)

\section{INTRODUCTION}

Herbage is the main source of food for cattle and also the most practical and low-cost alternative available to all farmers. Thus, the establishment and maintenance of more productive, better-quality pastures have been achieved through research aimed at increasing the production of forage plants from the pasture and consequently the animal yield (HU et al., 2014, MONJARDINO et al. 2015, CAMPOS et al. 2016).

Among the forage plants used by animals, grasses of the genus Brachiaria are the main option to feed the Brazilian beef cattle herd. According to Paiva et al. (2015) and Hungria et al. (2016), a broader use of Brachiaria species and/or cultivars has been possible because of their desirable features. Additionally, they are important sources of fibrous carbohydrates to provide energy to ruminants (MORAIS et al. 2014, FUKUSHIMA et al. 2015, ANDRADE et al. 2016). Of the Brachiaria species most commonly found in Brazilian pastures, Brachiaria humidicola stands out for its rusticity and survival ability even under adverse climatic conditions. Nakamura et al. (2005) stated that Brachiaria humidicola withstands drought and humidity and survives under low nutrient availability.

The adaptive capacity of Brachiaria humidicola may be associated with its structure, morphology and production system. In this way, to strategically define the best management strategy for Brachiaria humidicola cultivars, it is important to know the growth process of forage plants in detail. For grasses, tissue turnover must be analyzed, as it is influenced by climatic factors such as light, water, temperature and also the soil fertility (BASSO et al. 2010, MEIRELLES et al. 2011, SARATH et al. 2014, NASCA et al. 2015). Interactions among these morphogenetic variables determine the structural traits of grasses (COSTA et al. 2011). Information about morphogenetic traits can be used for identifying and planning forage management strategies to ensure longevity, productivity and sustainability to the ecosystem (PEREIRA et al. 2011, REZENDE et al. 2015).

This study was conducted with to determine structural and morphological differences among three different Brachiaria cultivars - common, Llanero and Tupi - subjected to continuous grazing, in four seasons of the year. 


\section{MATERIAL AND METHODS}

The experimental trial was conducted at the Animal Science Station of Extremo Sul (ESSUL), CEPLAC, located in the city of Itabela $\left(16^{0} 39^{\prime} \mathrm{S}\right.$ and $\left.39^{\circ} 30^{\prime} \mathrm{W}\right)$, BA, Brazil.
REZENDE, C. P. et al.

The area is part of the Atlantic Forest ecosystem, and the local climate is a transition between the Af and Am types, according to the Köppen classification. The region has an annual precipitation of $1,311 \mathrm{~mm}$ and an average temperature of $25^{\circ} \mathrm{C}$, without a defined dry season (Figure 1).

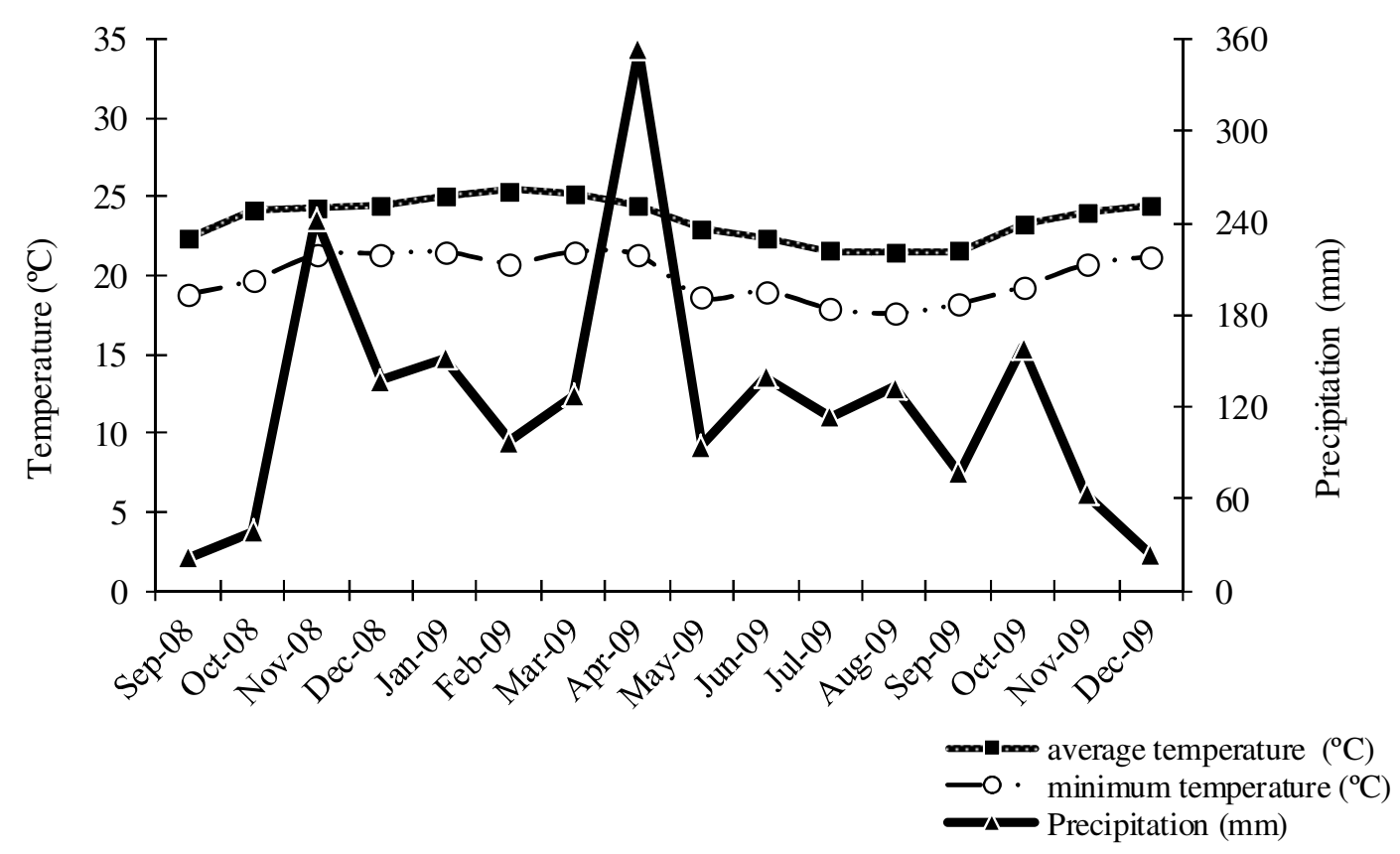

Figure 1. Climatic data from the Animal Science Station in the period from September 2008 to December 2009.

The soil is a sandy ( $>700 \mathrm{~g}$ sand $/ \mathrm{kg}$ ) Ultisol (fine-loamy, kaolinitic, isohyperthermic Typic Paleudult). At the upper $20 \mathrm{~cm}$ layer, the average chemical properties of the soil were: $\mathrm{pH}$ in $\mathrm{H}_{2} \mathrm{O}=$ 6.2; $\mathrm{Al}=0.1 \mathrm{cmol}_{\mathrm{c}} / \mathrm{dm}^{3} ; \mathrm{Ca}=2.6 \mathrm{cmol}_{\mathrm{c}} / \mathrm{dm}^{3} ; \mathrm{Mg}=$ $0.4 \mathrm{cmol}_{\mathrm{c}} / \mathrm{dm}^{3} ; \mathrm{K}=0.2 \mathrm{cmol}_{\mathrm{c}} / \mathrm{dm}^{3}$; available $\mathrm{P}=2.9$ $\mathrm{mg} / \mathrm{dm}^{3}$; cation exchange capacity $=6.8 \mathrm{cmol}_{\mathrm{c}} / \mathrm{dm}^{3}$; sum of bases $=3.2 \mathrm{cmol}_{\mathrm{c}} / \mathrm{dm}^{3} ;$ base saturation $=$ $47.06 \%$; and organic matter $=1.419 \mathrm{dag} / \mathrm{kg}$.

The experimental area consisted of nine 1.5ha paddocks, in which seeds of three Brachiaria humidicola cultivars - common, Llaneiro and Tupi - were planted. In the preparation of the soil, 1,000 $\mathrm{kg} / \mathrm{ha}$ dolomitic limestone were applied after soil analysis, and $50 \mathrm{~kg} / \mathrm{ha} \mathrm{P}_{2} \mathrm{O}_{5}$ were used at planting.

The tissue turnover of commercial grasses humidicola, dictyoneura and Tupi was studied during the first year of use of the pastures, in four periods: February to March; May to June; July to August; and November to December, corresponding to the summer, fall, winter and spring seasons, respectively. Measurements were taken every two days, totaling 125 days of evaluation. A continuous grazing management with variable stocking rate was adopted as a function of the herbage allowance of $4 \%$ green-herbage mass, using Zebu crossbred steers with an initial live weight of $210 \mathrm{~kg}$.

A randomized complete experimental design with five replicates was employed. The areas in each pasture were separated by using $1.20-\mathrm{m}-$ sided exclusion cages. Five tillers were isolated in each cage and identified.

Stem length (from the soil to the ligule of the youngest fully expanded leaf) and the length of each green leaf blade (from the ligule to the tip or end of the green part, in fully expanded leaves; and from the ligule of the previous leaf to the tip, in emerging leaves) were measured. With these determinations, it was possible to calculate the following variables:

Stem elongation rate $(\mathrm{cm} /$ tiller/day $)$ : calculated as the difference between final and initial stem lengths divided by the number of days involved;

Leaf elongation rate $(\mathrm{cm} /$ leaf/day): calculated as the difference between final and initial lengths of emerging leaves divided by the number of days involved; 
Number of live leaves per tiller: obtained by counting the number of green leaves (fully expanded leaves + emerging leaves) on the tiller. Leaves were considered dead when over $50 \%$ of their area had turned yellow; and

Phyllochron (days/leaf): calculated as the number of days of the evaluation period divided by the difference between the final and initial number of live leaves (the inverse of leaf appearance rate), as described by Lemaire \& Chapman (1996).

The data were subjected to homogeneity test and variance analysis using the ANOVA procedure (for balanced data) of the options of SAS software (SAS, 1996). Means were compared by Tukey's test at $5 \%$ significance.

\section{RESULTS}

Plant height; tiller length; number of live leaves; stem elongation rate; number of expanding, emerging and senescent leaves; fully expanded- and emerging-leaf lengths; leaf appearance rate; leaf elongation rate; and phyllochron varied $(\mathrm{P}<0.05)$ among the $B$. humidicola cultivars (Tables 1,2 and $3)$.

Llanero grass had the greatest plant height $(\mathrm{P}<0.05)$ among the cultivars. With respect to tiller length, although not significant $(\mathrm{P}>0.05)$ for the studied cultivars in the fall, winter and spring, both the common and Tupi grasses had a shorter length $(\mathrm{P}<0.05)$ in the summer (Table 1$)$.

Table 1. Mean values for plant height and lengths of tiller and expanded and emerging leaves of three Brachiaria cultivars in the four seasons of the year

\begin{tabular}{|c|c|c|c|c|}
\hline \multirow{2}{*}{ Grass } & \multicolumn{4}{|c|}{ Season } \\
\hline & Summer & Fall & Winter & Spring \\
\hline & \multicolumn{4}{|c|}{ Plant height $(\mathrm{cm})$} \\
\hline Common & $8.80 \mathrm{~b}$ & $11.73 \mathrm{a}$ & $10.75 \mathrm{a}$ & $13.13 \mathrm{a}$ \\
\hline Llanero & $17.73 \mathrm{a}$ & $14.69 \mathrm{a}$ & $13.30 \mathrm{a}$ & $15.12 \mathrm{a}$ \\
\hline Tupi & $6.56 \mathrm{~b}$ & $12.38 \mathrm{a}$ & $11.41 \mathrm{a}$ & $14.92 \mathrm{a}$ \\
\hline \multirow[t]{2}{*}{ LSD } & 4.58 & 6.04 & 6.77 & 4.49 \\
\hline & \multicolumn{4}{|c|}{ Tiller length $(\mathrm{cm})$} \\
\hline Common & $3.68 \mathrm{~b}$ & $5.29 \mathrm{a}$ & $5.44 \mathrm{a}$ & $7.09 \mathrm{a}$ \\
\hline Llanero & $6.58 \mathrm{a}$ & $7.98 \mathrm{a}$ & $7.32 \mathrm{a}$ & $9.33 \mathrm{a}$ \\
\hline Tupi & $1.94 \mathrm{~b}$ & $5.35 \mathrm{a}$ & $6.33 \mathrm{a}$ & $9.94 \mathrm{a}$ \\
\hline \multirow{2}{*}{ LSD } & 2.35 & 6.47 & 6.45 & 4.86 \\
\hline & \multicolumn{4}{|c|}{ Expanded-leaf length $(\mathrm{cm})$} \\
\hline Common & $4.17 \mathrm{a}$ & $4.17 \mathrm{a}$ & $4.17 \mathrm{a}$ & $4.17 \mathrm{a}$ \\
\hline Llanero & $4.14 \mathrm{a}$ & $4.14 \mathrm{a}$ & $4.14 \mathrm{a}$ & $4.14 \mathrm{a}$ \\
\hline Tupi & $2.09 \mathrm{~b}$ & $2.09 \mathrm{~b}$ & $2.09 \mathrm{~b}$ & $2.09 \mathrm{~b}$ \\
\hline \multirow[t]{2}{*}{ LSD } & 1.15 & 1.15 & 1.15 & 1.15 \\
\hline & \multicolumn{4}{|c|}{ Emerging-leaf length (cm) } \\
\hline Common & $2.72 \mathrm{ab}$ & $2.72 \mathrm{ab}$ & $2.72 \mathrm{ab}$ & $2.72 \mathrm{ab}$ \\
\hline Llanero & $3.21 \mathrm{a}$ & $3.21 \mathrm{a}$ & $3.21 \mathrm{a}$ & $3.21 \mathrm{a}$ \\
\hline Tupi & $1.59 \mathrm{~b}$ & $1.59 \mathrm{~b}$ & $1.59 \mathrm{~b}$ & $1.59 \mathrm{~b}$ \\
\hline LSD & 1.22 & 1.22 & 1.22 & 1.22 \\
\hline
\end{tabular}

Means followed by the same letters in the columns, among cultivars, in the same season, do not differ statistically by Tukey's test at $5 \%$ significance. $\mathrm{LDS}=$ least significant difference.

Although the common cultivar was influenced in the summer in terms of plant height, it showed greater values $(\mathrm{P}<0.05)$ in this season as compared with Tupi and Llanero grasses; there was no difference for the other periods. For tiller growth, Llanero cultivar showed higher values $(\mathrm{P}<0.05)$ than common and Tupi cultivars, in the summer (Table 1). The number of live and expanded leaves in Tupi grass was lower $(\mathrm{P}<0.05)$ than those found in Llanero and common cultivars. There was no significant difference $(\mathrm{P}>0.05)$ for the number of emerging leaves between the evaluated cultivars in all seasons of the year (Table 2).

The seasons of the year also did not affect the number of the leaves in the grass cultivars. On the other hand, the common cultivar presented a higher number of live, expanded and senescent leaves in all seasons $(\mathrm{P}<0.05)$ as compared with the other cultivars (Table 2). 
Table 2. Mean number of live, expanded, emerging and senescent leaves in three cultivars of Brachiaria in the four seasons of the year

\begin{tabular}{|c|c|c|c|c|}
\hline \multirow{2}{*}{ Grass } & \multicolumn{4}{|c|}{ Season } \\
\hline & Summer & Fall & Winter & Spring \\
\hline & \multicolumn{4}{|c|}{$\mathrm{N}$ of live leaves } \\
\hline Common & $5.00 \mathrm{a}$ & $5.00 \mathrm{a}$ & $5.00 \mathrm{a}$ & $5.00 \mathrm{a}$ \\
\hline Llanero & $3.47 \mathrm{~b}$ & $3.47 \mathrm{~b}$ & $3.47 \mathrm{~b}$ & $3.47 \mathrm{~b}$ \\
\hline Tupi & $2.38 \mathrm{~b}$ & $2.38 \mathrm{~b}$ & $2.38 \mathrm{~b}$ & $2.38 \mathrm{~b}$ \\
\hline \multirow[t]{2}{*}{ LSD } & 1.67 & 1.67 & 1.67 & 1.67 \\
\hline & \multicolumn{4}{|c|}{$\mathrm{N}$ of expanded leaves } \\
\hline Common & $3.63 \mathrm{a}$ & $3.63 \mathrm{a}$ & $3.63 \mathrm{a}$ & $3.63 \mathrm{a}$ \\
\hline Llanero & $2.43 \mathrm{~b}$ & $2.43 \mathrm{~b}$ & $2.43 \mathrm{~b}$ & $2.43 \mathrm{~b}$ \\
\hline Tupi & $1.45 \mathrm{~b}$ & $1.45 \mathrm{~b}$ & $1.45 \mathrm{~b}$ & $1.45 \mathrm{~b}$ \\
\hline \multirow[t]{2}{*}{ LSD } & 1.42 & 1.42 & 1.42 & 1.42 \\
\hline & \multicolumn{4}{|c|}{$\mathrm{N}$ of emerging leaves } \\
\hline Common & $1.19 \mathrm{a}$ & $1.19 \mathrm{a}$ & $1.19 \mathrm{a}$ & $1.19 \mathrm{a}$ \\
\hline Llanero & $1.04 \mathrm{a}$ & $1.04 \mathrm{a}$ & $1.04 \mathrm{a}$ & $1.04 \mathrm{a}$ \\
\hline Tupi & $0.92 \mathrm{a}$ & $0.92 \mathrm{a}$ & $0.92 \mathrm{a}$ & $0.92 \mathrm{a}$ \\
\hline \multirow[t]{2}{*}{ LSD } & 0.33 & 0.33 & 0.33 & 0.33 \\
\hline & \multicolumn{4}{|c|}{$\mathrm{N}$ of senescent leaves } \\
\hline Common & $1.70 \mathrm{a}$ & $1.70 \mathrm{a}$ & $1.70 \mathrm{a}$ & $1.70 \mathrm{a}$ \\
\hline Llanero & $0.13 \mathrm{~b}$ & $0.13 \mathrm{~b}$ & $0.13 \mathrm{~b}$ & $0.13 \mathrm{~b}$ \\
\hline Tupi & $0.09 \mathrm{~b}$ & $0.09 \mathrm{~b}$ & $0.09 \mathrm{~b}$ & $0.09 \mathrm{~b}$ \\
\hline LSD & 0.51 & 0.51 & 0.51 & 0.51 \\
\hline
\end{tabular}

Means followed by the same letters in the columns, among cultivars, in the same season, do not differ statistically by Tukey's test at $5 \%$. LDS = least significant difference.

Stem elongation rate differed among the cultivars $(\mathrm{P}<0.05)$. Llanero grass showed the highest elongation rate, remaining with the highest mean values, followed by Tupi grass, without significant differences during the summer (Table 3 ). In the other seasons, the grasses did not show differences $(\mathrm{P}>0.05)$ for stem elongation rate. With respect to leaf elongation rate, there were no significant differences $(\mathrm{P}>0.05)$ among the cultivars over the year.

Table 3. Leaf elongation rate ( $\mathrm{cm} / \mathrm{leaf} / \mathrm{day})$, stem elongation rate $(\mathrm{cm} / \mathrm{tiller} / \mathrm{day})$, leaf appearance rate (leaves/day), and phyllochron (days/leaf) in the four seasons of the year

\begin{tabular}{|c|c|c|c|c|}
\hline \multirow{2}{*}{ Grass } & \multicolumn{4}{|c|}{ Season } \\
\hline & Summer & Fall & Winter & Spring \\
\hline & \multicolumn{4}{|c|}{ Leaf elongation rate $(\mathrm{cm} / \mathrm{leaf} /$ day) } \\
\hline Common & $0.52 \mathrm{a}$ & $0.55 \mathrm{a}$ & $0.55 \mathrm{a}$ & $0.37 \mathrm{a}$ \\
\hline Llanero & $0.93 \mathrm{a}$ & $0.55 \mathrm{a}$ & $0.57 \mathrm{a}$ & $0.65 \mathrm{a}$ \\
\hline Tupi & $0.37 \mathrm{a}$ & $0.58 \mathrm{a}$ & $0.45 \mathrm{a}$ & $0.65 \mathrm{a}$ \\
\hline \multirow[t]{2}{*}{ LSD } & 0.93 & 0.27 & 0.29 & 0.41 \\
\hline & \multicolumn{4}{|c|}{ Stem elongation rate $(\mathrm{cm} /$ tiller/day) } \\
\hline Common & $0.64 \mathrm{ab}$ & $0.28 \mathrm{a}$ & $0.37 \mathrm{a}$ & $0.40 \mathrm{a}$ \\
\hline Llanero & $0.88 \mathrm{a}$ & $0.46 \mathrm{a}$ & $0.39 \mathrm{a}$ & $1.13 \mathrm{a}$ \\
\hline Tupi & $0.22 \mathrm{~b}$ & $0.35 \mathrm{a}$ & $0.42 \mathrm{a}$ & $0.68 \mathrm{a}$ \\
\hline \multirow[t]{2}{*}{ LSD } & 0.63 & 0.43 & 0.42 & 0.89 \\
\hline & \multicolumn{4}{|c|}{ Leaf appearance rate (leaves/day) } \\
\hline Common & $0.17 \mathrm{~b}$ & $0.08 \mathrm{a}$ & $0.11 \mathrm{a}$ & $0.11 \mathrm{a}$ \\
\hline Llanero & $0.31 \mathrm{ab}$ & $0.06 \mathrm{a}$ & $0.14 \mathrm{a}$ & $0.09 \mathrm{a}$ \\
\hline Tupi & $0.62 \mathrm{a}$ & $0.07 \mathrm{a}$ & $0.21 \mathrm{a}$ & $0.09 \mathrm{a}$ \\
\hline \multirow[t]{2}{*}{ LSD } & 0.32 & 0.04 & 0.11 & 0.08 \\
\hline & \multicolumn{4}{|c|}{ Phyllochron (days/leaf) } \\
\hline Common & $6.18 \mathrm{a}$ & $16.26 \mathrm{a}$ & $10.04 \mathrm{a}$ & $11.10 \mathrm{a}$ \\
\hline Llanero & $8.37 \mathrm{a}$ & $26.52 \mathrm{a}$ & $9.04 \mathrm{a}$ & $15.99 \mathrm{a}$ \\
\hline Tupi & $11.72 \mathrm{a}$ & $19.26 \mathrm{a}$ & $5.90 \mathrm{a}$ & $12.17 \mathrm{a}$ \\
\hline LSD & 6.35 & 15.01 & 4.83 & 12.35 \\
\hline
\end{tabular}

Means followed by the same letters in the columns, among cultivars, in the same season, do not differ statistically by Tukey's test at $5 \%$ significance. LDS $=$ least significant difference. 
Leaf appearance rate differed $(\mathrm{P}<0.05)$ among the Brachiaria cultivars only in the summer; Tupi cultivar displayed greater values for this variable than common, and was similar to Llanero. In the other seasons of the year, all cultivars responded equally $(\mathrm{P}>0.05)$ (Table 3$)$.
Common and Llanero cultivars did not have significant differences for leaf lifespan $(\mathrm{P}>0.05)$. Tupi grass presented lower values $(\mathrm{P}<0.05)$ than the other cultivars in the summer, winter and spring, but statistically the same value in the fall. Leaf lifespan varied according to the time of the year (Table 4).

Table 4. Leaf lifespan (days) in the four seasons of the year

\begin{tabular}{lcccc}
\hline \multirow{2}{*}{ Grass } & \multicolumn{4}{c}{ Season } \\
\cline { 2 - 5 } & Summer & Fall & Winter & Spring \\
\hline & & \multicolumn{2}{c}{ Leaf lifespan (days) } & \\
Common & $4.17 \mathrm{a}$ & $5.28 \mathrm{a}$ & $4.46 \mathrm{a}$ & $4.86 \mathrm{a}$ \\
Llanero & $4.14 \mathrm{a}$ & $5.84 \mathrm{a}$ & $4.83 \mathrm{a}$ & $4.76 \mathrm{a}$ \\
Tupi & $2.09 \mathrm{~b}$ & $5.44 \mathrm{a}$ & $4.08 \mathrm{~b}$ & $4.37 \mathrm{~b}$ \\
LSD & 1.15 & 1.20 & 1.26 & 2.37 \\
\hline
\end{tabular}

Means followed by the same letters in the columns, among cultivars, in the same season, do not differ statistically by Tukey's test at $5 \%$. LDS $=$ least significant difference.

\section{DISCUSSION}

Results for the growth variables plant height and tiller length demonstrated that cultivar Llanero is more tolerant to climatic alterations inherent to the summer, whereas the other cultivars had their size reduced in this time of the year (Table 1).

Therefore, despite the smaller size observed for the common cultivar in the summer, this cultivar showed better performance than the others in this season in terms of number of live leaves. Additionally, the number of live leaves obtained in this cultivar was similar to those found by Marcelino et al. (2006), who subjected B. brizantha cv. Marandu to more severe defoliation intensities and a harvest height ranging from 10 to $20 \mathrm{~cm}$.

Under these same conditions, Fagundes et al. (2006) obtained, with B. decumbens cv. Basilisk, greater results for final leaf length, which ranged from 9.75 to $15.96 \mathrm{~cm}$ according to the season of the year. In an experiment with Brachiaria brizantha cv. Marandú, Alexandrino et al. (2005) found an average leaf size that ranged from 1.57 to $2.01 \mathrm{~cm}$ according to the frequency of harvests and different nitrogen doses. For those authors, the average number of leaves is an important morphogenetic trait, because it is a combination of leaf appearance and tiller elongation.

Llanero and Tupi grass were not affected by the field conditions in the different seasons of the year, presenting low values that were similar for number of senescent leaves in almost all seasons. In all seasons, cv. common had approximately $1000 \%$ more senescent leaves than Tupi and Llanero grasses.

Casagrande et al. (2010) concluded that environmental variables and genetic characteristics have a greater influence on the morphogenetic traits than management actions. This was also reported by Silveira et al. (2010), who demonstrated that leaf appearance rate and number of dead leaves per tiller varied with grass cultivars, with the highest value recorded for Tupi as compared with the common cultivar.

The results of this trial demonstrate that the Llanero and Tupi grasses had an average phyllochron of 14.98 and 12.26 days/leaf, respectively, whereas for the common grass, the time for the appearance of two consecutive leaves was 10.89 days. No significance was found for phyllochron among the different cultivars. Barbosa et al. (2013) mentioned higher average phyllochron values for Brachiaria cv. Tupi (24.1 and 24.2 days/leaf for humid and dry periods of the year, respectively). These results prove the adaptability of this cultivar, even in periods of low rainfall. By contrast, in B. brizantha cv. Marandu, the greatest phyllochron was observed at the lowest defoliation frequencies, with results between 10.86 and 14.93 days (MARCELINO et al. 2006).

Mattos et al. (2005) evaluated the tolerance to drought and elongation of three commercial species and three accessions of Brachiaria and observed an average leaf appearance rate of 0.17 and 0.16 leaves/days for cultivars Tupi and Llanero, respectively, whose values corresponded to a phyllochron of 5.9 and 6.34 days/leaf. However, the average leaf appearance rate was 0.09 and 0.10 $\mathrm{cm} /$ day/tiller for cultivars Tupi and Llanero, respectively; these values were lower than those presented here, because the plants were under waterstress conditions.

The effect of the transition from dry season to the beginning of rains in the summer made this season the period with the largest variations in results among the cultivars. 
The greater variation in structural traits between cultivars in the summer may be associated with the adaptation of each one of them. Thus, the main differences were observed for number of live leaves and tillers, whereby grasses with higher values for these variables survived longer. This hypothesis can be verified in the experiment conducted by Barbosa et al. (2013), who worked with Brachiaria cultivars (Tully and Tupi) in different periods of the year (dry and rainy) and found longer lifespan and greater leaf length as a result of the adaptability of cultivars.

Similarly, Santos et al. (2008) worked with deferred Brachiaria decumbens and obtained similar results to those found in this experiment. According to Paciullo et al. (2008), this variation in growth factors reflects the activity of adaptive mechanisms to ensure regrowth and perenniality, i.e., the reduction in leaf appearance rate when climatic conditions were unfavorable was partly compensated for by the increase in leaf lifespan.

\section{CONCLUSION}

The common cultivar presented the largest number of live, expanded and emerging leaves, and consequently the largest number of senescent leaves. However, this grass displayed the lowest leaf appearance rate, in the summer.

Llanero grass stood out for having the greatest plant height and tiller and leaf lengths, as a result of the greater stem and leaf elongation rates. Tupi grass had the lowest performance as compared with the other cultivars.

RESUMO: O experimento foi realizado com o objetivo de avaliar as características morfogenéticas de três cultivares de Brachiaria humidicola (common, Llanero e Tupi), submetido a pastejo contínuo, em quatro estações do ano. Foi utilizado delineamento em blocos casualizados, com cinco repetições. As avaliações do volume de tecido vegetal foram realizadas no verão, outono, inverno e primavera, e as medidas foram tomadas a cada dois dias. Determinaram-se o comprimento da haste e o comprimento de cada lâmina de folha verde. Com essas determinações, foram calculados: taxa de alongamento ( $\mathrm{cm} /$ perfilho / dia), taxa de alongamento foliar ( $\mathrm{cm} /$ folha / dia), número de folhas vivas por perfilho e filocromo (dia / folha). A maior taxa de aparecimento de folhas foi obtida na grama Tupi no período de verão, e o menor aparecimento ocorreu no cultivar Llanero, durante o inverno. O menor filocromo (5,90 dias / folha) foi verificado no cultivar Tupi, no inverno, enquanto no cultivares Llanero e common o filocromo médio foi de 9,04 e 10,04 dias / folha, respectivamente. Devido ao efeito da transição, a partir da estação seca para o início das chuvas no verão, foi constatado que as maiores variações nos resultados dos diferentes cultivares, ocorreram nesta época. O cultivar, Llanero se destacou para os maiores valores da planta, resultante das maiores taxas de alongamento de caule e folhas. O cultivar Tupi teve o menor desempenho em comparação com os outros.

PALAVRAS-CHAVE: Emissão de folhas. Phyllocladus. Filocromo. Estrutura (Fonte: CAB thesaurus)

\section{REFERENCES}

ALEXANDRINO, E.; NASCIMENTO-JUNIOR, D.; REGAZZI, A. J.; MOSQUIM, P. R.; ROCHA, F. C.; SOUZA, D. P. Morphogenic and structural traits of Brachiaria brizantha cv. Marandu submitted to different levels of Nitrogen and frequency harvest. Acta Scientiarum Agronomy, Maringá, v. 27, p. 17-24, 2005.

ANDRADE, A. S.; SANTOS, P. M.; PEZZOPANE, J. R. M.; ARAUJO, L. C.; PEDREIRA, B. C.; PEDREIRA, C. G. S.; MARIN, F. R.; LARA, M. A. S. Simulating tropical forage growth and biomass accumulation: an overview of model development and application. Grass and Forage Science, Japan, v. 71, p. 54-65, 2016. https://doi.org/10.1111/gfs.12177

BARBOSA, R. A.; AMARAL, P. N. C.; SBRISSIA, A. F.; CAMARA, T. T. Morphophysiological adaptations of Brachiaria humidicola cultivars under grazing. Tropical Grassland - Forrajens Tropicales. Colombia, v. 1, p. 50-51, 2013.

BASSO, K. C.; CECATO, U.; LUGÃO, S. M. B.; GOMES, J. A. N.; BARBERO, L. M.; MOURÃO, G. B. Morphogenesis and dynamics of tillering in a pasture of Panicum maximum Jacq. cv. IPR-86 Millennium under increasing doses of nitrogen. Revista Brasileira de Saúde e Produção Animal , Salvador, v. 11, p. 976-989, 2010. 
CAMPOS, F. P.; NICÁCIO, D. R. O.; SARMENTO, P.; CRUZ, M. C. P.; SANTOS, T. M.; FARIA, A. F. G.; FERREIRA, M. E.; CONCEIÇÃO, M. R. G.; LIMA, C. G. Chemical composition and in vitro ruminal digestibility ofhand-plucked samples of Xaraes palisade grass fertilizedwith incremental levels of nitrogen. Animal Feed Science and Technology, v. 215, p. 1-12, 2016. https://doi.org/10.1016/j.anifeedsci.2015.12.013

CASAGRANDE, D. R.; RUGGIERI, A. C.; JANUSCKIEWIC, E. R.; GOMIDE, J. A.; REIS, R. A.; VALENTE, A. L. S. Morphogenetic and structural traits of Marandugrass pasture under continuous grazing with different forage supply. Revista Brasileira de Zootecnia, Viçosa, v. 39, p. 2108-2115, 2010. https://doi.org/10.1590/S1516-35982010001000002

COSTA, N. L.; GIANLUPPI, V.; MORAES, A. Forage production and morphogenesis of "Trachypogon vestitus" under different regrowth ages in the Roraima's savannas. Revista Brasileira de Saúde e Produção Animal, Salvador, v. 12, p. 935-948, 2011.

FUKUSHIMA, R. S.; BACHA, C. B.; FUZETO, A. P.; PORT, A. C. R.; HERLING, V. R.; VELÁSQUEZ, A. V. Utilization of equations to predict carbohydrate fractions in some tropical grasses. Animal Feed Science and Technology, v. 208, p. 12-22, 2015. https://doi.org/10.1016/j.anifeedsci.2015.06.016

HU, H.; LIU, Y.; LI, Y.; LU, D.; GAO, M. Use of the N-alkanes to Estimate Intake, Apparent Digestibility and Diet Composition in Sheep Grazing on Stipa breviflora Desert Steppe. Journal of Integrative Agriculture, v. 13, p. 1065-1072, 2014. https://doi.org/10.1016/S2095-3119(13)60502-X

HUNGRIA, M.; NOGUEIRA, M. A.; ARAUJO, R. S. Inoculation of Brachiaria spp. with the plant growthpromoting bacterium Azospirillum brasilense: An environment-friendly component in the reclamation of degraded pastures in the tropics. Agriculture, Ecosystems and Environment, v. 221, p. 125-131, 2016. https://doi.org/10.1016/j.agee.2016.01.024

LEMAIRE, G., CHAPMAN, D. Tissue flows in grazed plant communities. In: HODGSON, J., ILLIUS, A. W. (Ed). The ecology and management of grazing systems. London: CAB International. pp. 3-36. 1996.

MARCELINO, K. R. A.; NASCIMENTO JUNIOR, D.; SILVA, S. C.; EUCLIDES, V. P. B.; FONSECA, D. M. Morphogenetic and structural traits and herbage production of marandugrass under intensities and frequencies of defoliation. Revista Brasileira de Zootecnia, Viçosa, v. 35, p. 2243-2252, 2006. https://doi.org/10.1590/S1516-35982006000800007

MATTOS, J. L. S.; GOMIDE, J. A.; HUAMAN, C. A.M. Effect of water deficit and flooding on the growth of Brachiaria species in the field. Revista Brasileira de Zootecnia , Viçosa, v. 34, p. 755-764, 2005. https://doi.org/10.1590/S1516-35982005000300006

MEIRELLES, M. L.; FRANCO, A. C.; FARIAS, S. E. M.; Bracho, R. Evapotranspiration and plantatmospheric coupling in a Brachiaria brizantha pasture in the Brazilian savannah region. Grass and Forage Science, v. 66, p. 206-213, 2011. https://doi.org/10.1111/j.1365-2494.2010.00777.x

MONJARDINO, M.; MACLEOD, N.; MCKELLAR, L.; PRESTWIDGE, D. Economic evaluation of irrigated forage production in a beef cattle operation in the semi-arid tropics of northern Australia. Agricultural Systems, v. 139, p. 122-143, 2015. https://doi.org/10.1016/j.agsy.2015.07.004

MORAIS, J. A. S.; QUEIROZ, M. F. S.; KELI, A.; VEGA, A.; FIORENTINI, G.; CANESIN, R. C.; REIS, R. A.; BERCHIELLI, T. T. Effect of supplementation frequency on intake, behaviorand performance in beef steers grazing Marandu grass. Animal Feed Science and Technology, v. 189, p. 63-71, 2014. https://doi.org/10.1016/j.anifeedsci.2014.01.005

NAKAMURA, T.; MIRANDA, C. H. B.; OHWAKI, Y.; VALÉIO, J. R.; KIM, Y.; MACEDO, M. C. M. Characterization of Nitrogen Utilization by Brachiaria Grasses in Brazilian Savannas (Cerrados). Soil Science Plant \& Nutrition, v. 61, n. 7, p. 973-979, 2005. https://doi.org/10.1111/j.1747-0765.2005.tb00136.x 
NASCA, J. A.; FELDKAMP, C. R.; ARROQUY, J. I.; COLOMBATTO, D. Efficiency and stability in subtropical beef cattle grazing systems in the northwest of Argentina. Agricultural Systems, v. 133, p. 85-96, 2014. https://doi.org/10.1016/j.agsy.2014.10.014

PACIULlO, D. S. C.; CAMPOS, N. R.; GOMIDE, C. A. M.; CASTRO, C. R. T.; TAVELA, R. C.; ROSSIELLO, R. O. P. Growth of signalgrass influenced by shading levels and season of the year. Pesquisa Agropecuária Brasileira, Brasília, v. 43, p. 917-923, 2008. https://doi.org/10.1590/S0100204X2008000700017

PAIVA, A. J.; PEREIRA, L. E. T.; SILVA, S. C.; DIAS, R. A. P. Identification of tiller age categories based on morphogenetic responses of continuously stocked marandu palisade grass fertilised with nitrogen. Ciência Rural, Maringá, v. 45, p. 867-870, 2015. https://doi.org/10.1590/0103-8478cr20120738

PEREIRA, V. V.; FONSECA, D. M.; MARTUSCELLO, J. A.; BRAZ, T. G. S.; SANTOS, M. V.; CECON, P. R. Morphogenic and structural characteristics of Panicum maximum Jacq. cv. Mombaça under three densities of fertilization with nitrogen. Revista Brasileira de Zootecnia, Viçosa, v. 40, p. 2681-2689, 2011. https://doi.org/10.1590/S1516-35982011001200010

REZENDE, A. V. F.; RABÊLO, H. S.; RABELO, C. H. S.; LIMA, P. P.; BARBOSA, L. A.; ABUD, M. C.; SOUZA, F. R. C. Structural, productive and bromatologic characteristcs of Tifton 85 and Jiggs grasses fertilized with some macronutrients. Semina: Ciências Agrárias, Londrina, v. 36, p. 1507-1518, 2015. https://doi.org/10.5433/1679-0359.2015v36n3p1507

SANTOS, M. E. R.; FONSECA, D. M.; EUCLIDES, V. P. B.; BALBINO, E. M.; SILVA, S. P.; MONNERAT, J. P. I. S. Forage nutritional value and its morphological components on Brachiaria decumbens stockpiled forage. Boletim de Indústria Animal, Nova Odessa, v. 65, p. 303-311, 2008.

SARATH, G.; BAIRD, L. M.; MITCHELL, R. B. Senescence, dormancy and tillering in perennial $\mathrm{C}_{4}$ grasses. Plant Science, v. 217, p. 140-151, 2014. https://doi.org/10.1016/j.plantsci.2013.12.012

SAS. 1996. SAS Statistical analysis systems. Version 6.11. SAS Institute. 1996.

SILVEIRA, M. C. T; JUNIOR, D. N.; SILVA, S. C.; EUCLIDES, V. P. B.; MONTAGNER, D. B.; SBRISSIA, A. F.; RODRIGUES, C. S.; SOUSA, B. M. L.; PENA, K. S.; VILELA, H. H. Morphogenetic and structural comparative characterization of tropical forage grass cultivars under free growth. Sciencia Agricola, Piracicaba, v. 67, n. 2, p.136-142, 2010. https://doi.org/10.1590/S0103-90162010000200002 